\title{
Guillain-Barré syndrome supervening on meningitis in primary Epstein-Barr virus infection
}

\author{
Jeong-Yoon Lee, Jun-Sang Sunwoo, Kyum-Yil Kwon, Kyung Bok Lee, Moo-Young Ahn, and \\ Hakjae Roh \\ Departments of Neurology, Soonchunhyang University Seoul Hospital, Soonchunhyang University School of \\ Medicine, Seoul, Korea
}

Received: June 9, 2018

Revised: September 12, 2018

Accepted: October 3, 2018

\section{Correspondence to}

\section{Hakjae Roh}

Department of Neurology, Soonchunhyang University Seoul Hospital, Soonchunhyang University School of Medicine, 59 Daesagwan-ro, Yongsan-gu, Seoul 04401, Korea Tel: +82-2-709-9224

Fax: +82-2-795-3687

E-mail:newroh@schmc.ac.kr

\section{ORCID}

\section{Jeong-Yoon Lee}

http://orcid.org/0000-0002-4297-1791

Jun-Sang Sunwoo

http://orcid.org/0000-0001-8834-0568

\section{Kyum-Yil Kwon}

http://orcid.org/0000-0001-5443-0952

Kyung Bok Lee

http://orcid.org/0000-0003-2663-7483

Moo-Young Ahn

http://orcid.org/0000-0003-0329-5855

Hakjae Roh

http://orcid.org/0000-0002-0979-4279

Primary Epstein-Barr virus (EBV) infection can manifest with a broad spectrum of neurological complications. There are only rare reports of Guillain-Barré syndrome (GBS) supervening on meningitis in patients with primary EBV infection. Clear evidence of central nervous system infection makes it difficult for the clinicians to consider a diagnosis of GBS. We present a patient with GBS supervening on meningitis in primary EBV infection.

Key words: Epstein-Barr virus; Guillain-Barré syndrome; Meningitis

Primary Epstein-Barr virus (EBV) infection can manifest with a broad spectrum of neurological complications. There have been numerous reports of cases about cranial neuropathy, central nervous system (CNS) infection including meningitis, encephalomyelitis, and cerebellitis, and immune-mediated disorders such as multiple sclerosis, optic neuritis, and Guillain-Barré syndrome (GBS) in primary EBV infection..$^{1-3}$ However, to our knowledge, there are only rare reports of cases about primary EBV infection with GBS supervening on meningitis.

\section{CASE}

A 19-year-old woman presented with severe headache and fever that first appeared 3 days prior to admission. She had no history of any medical illness, prior medication, or traveling. She complained of malaise, nausea, and vomiting, but not sore throat or diarrhea. Her initial vital signs were a blood pressure of $111 / 72 \mathrm{mmHg}$, pulse rate of 131 beats/min, respiratory rate of 19 breaths $/ \mathrm{min}$, and body temperature of $39.2^{\circ} \mathrm{C}$. A physical examination revealed no signs of tonsillitis, pharyngitis, cervical lymph-node enlargement,

\footnotetext{
This is an Open Access article distributed under the terms of the Creative Commons Attribution Non-Commercial License (http:// creativecommons.org/licenses/by-nc/4.0) which permits unrestricted non-commercial use, distribution, and reproduction in any medium, provided the original work is properly cited.
} 
or skin lesions. On the initial neurological examination, she was alert and orientated. The findings of cranial nerve, motor, and sensory examinations were all unremarkable. Deep tendon reflexes were symmetrically preserved in all limbs, and no pathological reflexes were found. She had prominent neck stiffness. Laboratory findings indicated a white blood cell (WBC) count of 29,800/ $\mathrm{LL}$ and C-reactive protein of $5.56 \mathrm{mg} / \mathrm{dL}$. The cerebrospinal fluid (CSF) was clear, with an opening pressure of $224 \mathrm{mmH}_{2} \mathrm{O}, \mathrm{WBC}$ count of $297 / \mu \mathrm{L}$ (neutrophils dominant at 61\%), red blood cell (RBC) count of $15 / \mu \mathrm{L}$, total protein of $65 \mathrm{mg} / \mathrm{dL}$, and glucose of $70 \mathrm{mg} / \mathrm{dL}$ (serum glucose was at $109 \mathrm{mg} / \mathrm{dL}$ ). The results of polymerase chain reaction (PCR) for EBV DNA in both serum and CSF revealed positivity. Positive results were also found in other EBV-specific serology including virus capsid antigen (VCA) immunoglobulin M (IgM), VCA immunoglobulin G (lgG) and EBV nuclear antigen IgG (Table 1).

A diagnosis of primary EBV infection with meningitis was made. The laboratory findings were unremarkable for other viruses (CSF PCR for herpes simplex type 1 and 2, varicella zoster virus, human herpes virus 6, human cytomegalovirus, and parvovirus B19; serum antihepatitis A virus IgM and lgG; human immunodeficiency virus Ag/Ab combo; and sputum PCR for influenza virus A\&B), bacteria (CSF Gram stain and culture, Bactigen latex agglutination test, and serum Mycoplasma pneumoniae $\operatorname{lgM}$ and $\lg \mathrm{G}$ ), fungi (India ink stain, fungus culture, and cryptococcus antigen in (SF), tuberculosis (acid fast bacilli smear, Mycobacterium tuberculosis culture, and TB/NTM real-time PCR in CSF), syphilis (serum and CSF rapid plasma regain test), and parasites (specific antibodies to Clonorchis sinensis, Paragonimus westermani, cysticercus, and sparganum in (SF).

The next day the patient complained of difficulty in eye opening, swallowing, breathing, and voiding, and worsening of her general weakness. A neurological examination revealed mild bilateral peripheral type facial palsy, dysarthria, dysphagia, and ascending symmetrical flaccid quadriparesis (MRC grade 4). Sensory examinations were normal. Her deep tendon reflexes were decreased in all limbs, and no pathological reflexes were evident. Brain magnetic resonance imaging (MRI) revealed leptomeningeal enhancement with no parenchymal lesion (Fig. 1A). The findings of cervical, thoracic, and lumbar spine MRI were unremarkable (Fig. 1B). Chest and abdominopelvic computed tomography showed signs
Table 1. Epstein-Barr virus serological profiles

\begin{tabular}{|c|c|c|c|c|c|}
\hline & $\begin{array}{l}\text { VCA } \\
\text { IgM }\end{array}$ & VCA IgG & $\begin{array}{c}\text { EBNA } \\
\lg G\end{array}$ & $\begin{array}{c}\text { EBV } \\
\text { DNA } \\
\text { PCR } \\
\text { (serum) }\end{array}$ & $\begin{array}{l}\text { EBV } \\
\text { DNA } \\
\text { PCR } \\
\text { (CSF) }\end{array}$ \\
\hline On admission & Serum & $\begin{array}{c}\text { EBV DNA } \\
\text { PCR }\end{array}$ & Positive & Positive & Positive \\
\hline $\begin{array}{l}\text { Three weeks } \\
\text { from symptom } \\
\text { onset }\end{array}$ & CSF & Positive & Positive & Negative & Negative \\
\hline
\end{tabular}

VCA, viral capsid antigen; IgM, immunoglobulin $M$; IgG, immunoglobulin G; EBNA, EBV nuclear antigen; EBV, Epstein-Barr virus; PCR, polymerase chain reaction; CSF, cerebrospinal fluid.

of aspiration pneumonia. She was started on the treatment with intravenous (IV) acyclovir (10 mg/kg every 8 hours) for 14 days, IV piperacillin/tazobactam (4.5 g every 6 hours) for 10 days and intravenous immunoglobulin (IVIG) (400 $\mathrm{mg} / \mathrm{kg} /$ day) for 5 days.

Three days after being admitted, the patient underwent intubation with ventilator assistance and an indwelling urinary catheter. A neurological examination revealed spontaneous eye opening with incomplete eye closure. The fixation of both eyeballs, absence of corneal reflexes, facial diplegia, and symmetrical flaccid quadriplegia (MRC grade 0 or 1) were observed. Antiganglioside antibodies (anti-GQ1b, anti-GD1b and anti-GM1) in serum and PCR for Campylobacter jejuni in stool were all negative. A motor nerve conduction study (NCS) revealed a markedly decreased amplitude of the compound motor action potential in bilateral facial, median, ulnar, and peroneal nerves. The findings of a sensory NCS were normal in all limbs. F-waves in median, ulnar, peroneal, and tibial nerves and $\mathrm{H}$-reflex in calf muscles were both absent bilaterally. A blink reflex exhibited the absence of bilateral ipsilateral R1, ipsilateral R2, and contralateral R2 responses (Table 2). Follow-up brain MRI produced the same findings as the initial brain MRI. Electroencephalography (EEG) revealed no epileptiform discharge or slowing.

She reached nadir within 1 week, and follow-up CSF analysis was conducted 3 weeks from the symptom onset. Albuminocytologic dissociation was found, with an opening pressure of $186 \mathrm{mmH}_{2} \mathrm{O}, \mathrm{WBC}$ count of $\mathrm{O} / \mu \mathrm{L}$, RBC count of $\mathrm{O} / \mathrm{\mu L}$, total protein of $179 \mathrm{mg} / \mathrm{dL}$, and glucose of $94 \mathrm{mg} / \mathrm{dL}$. The titers of EBV-specific serological markers are presented 

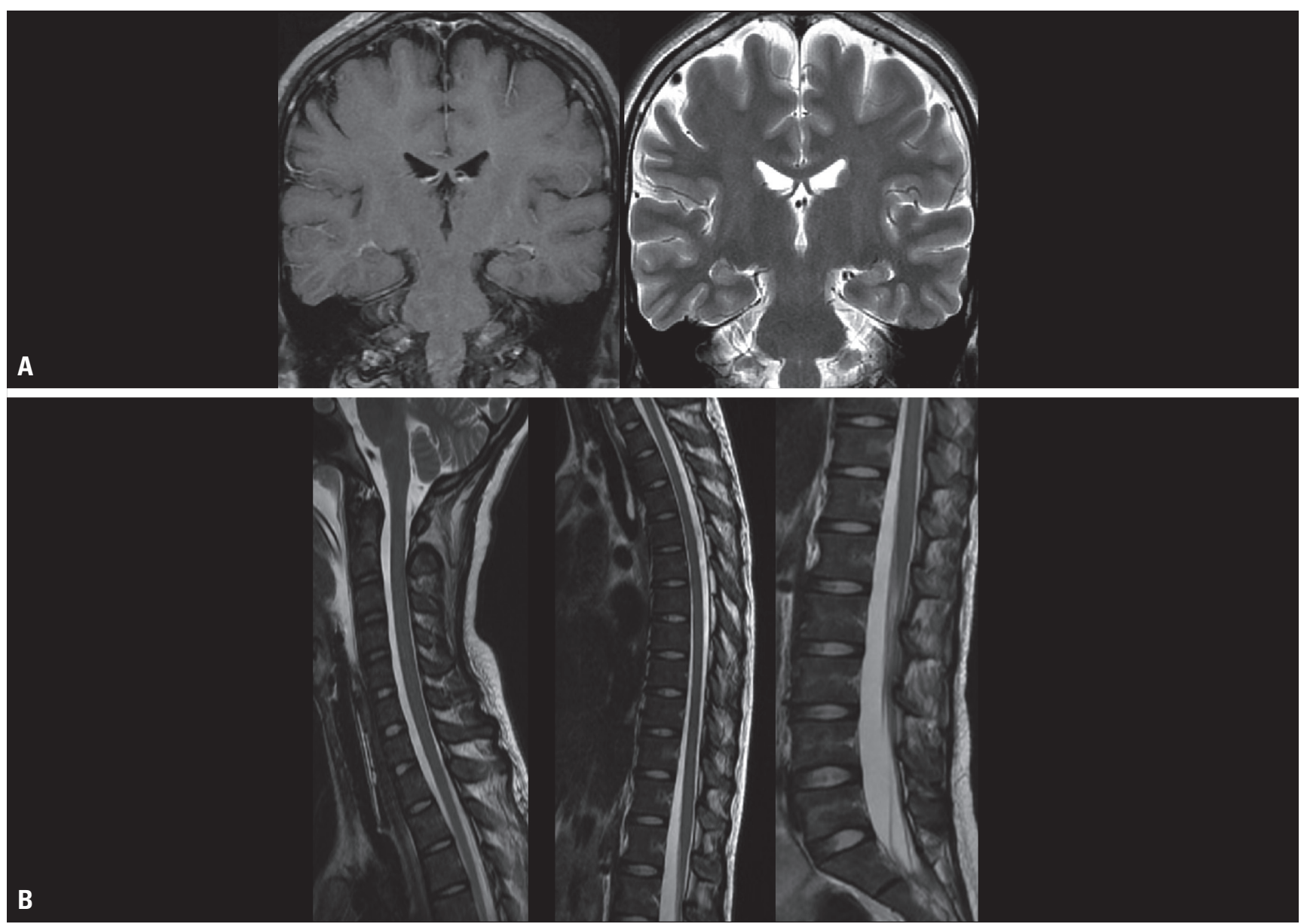

Fig. 1. (A) Leptomeningeal enhancement was found in contrast-enhanced T1-weighted brain magnetic resonance imaging (MRI) with no parenchymal lesion. The findings of T2-weighted brain MRI were unremarkable. (B) No spinal cord lesion was evident in cervical, thoracic, and lumbar spine MRI.

in Table 1. The results of follow-up motor and sensory NCSs were compatible with acute motor-sensory axonal neuropathy without conduction block (Table 2). During 2 months of hospitalization, her quadriparesis improved from MRC grade 0 to MRC grade 3 or 4 . The fixation of both eyeballs and facial diplegia showed complete recovery. The patient was transferred to the rehabilitation clinic.

\section{DISCUSSION}

GBS is diagnosed mainly based on the clinical presentation and supportive findings in CSF and electrodiagnostic studies. ${ }^{4}$ Among a wide variety of differential diagnoses, CNS infection must be differentiated from GBS. Fever at onset and an elevated WBC count (> 50/ $\mu \mathrm{L}$ ) in CSF makes the diagnosis of GBS doubtful. ${ }^{5}$ The current patient presented with classical symptoms of meningitis including fever, severe headache, and vomiting. Primary EBV infection with meningitis could be diagnosed from the results of EBV-specific serological markers and the EBV DNA PCR in both serum and CSF. ${ }^{6,7}$ Although the patient showed rapidly progressive flaccid quadriparesis, encephalomyelitis should have been suspected due to the dysfunction of multiple cranial nerves, respiration, and bladder at the initial presentation. However, no brainstem or spinal cord lesion was found in neuroimaging, and EEG showed a normal posterior-dominant rhythm with no abnormality. Symmetrical flaccid quadriplegia with areflexia that reached plateau within 1 week and the findings of electrodiagnostic studies were highly suggestive 
Table 2. Electrophysiological findings

\begin{tabular}{|c|c|c|c|c|c|c|}
\hline \multirow[b]{2}{*}{ Nerve sites } & \multicolumn{3}{|c|}{ Initial } & \multicolumn{3}{|c|}{ Three weeks from symptom onset } \\
\hline & Latency (ms) & Amplitude (mV) & $\begin{array}{l}\text { Conduction } \\
\text { velocity }(\mathrm{m} / \mathrm{s})\end{array}$ & Latency (ms) & Amplitude (mV) & $\begin{array}{c}\text { Conduction } \\
\text { velocity }(\mathrm{m} / \mathrm{s})\end{array}$ \\
\hline \multicolumn{7}{|l|}{ Motor NCS } \\
\hline \multicolumn{7}{|l|}{ Median } \\
\hline Wrist & $\mathrm{NP} / 4.5$ & NP/0.9 & & $4.9 / 6.0$ & $0.2 / 0.2$ & \\
\hline Elbow & NP/9.3 & NP/0.8 & $\mathrm{NP} / 47$ & $\mathrm{NP} / 11.0$ & NP/0.1 & $N P / 41$ \\
\hline Axilla & 10.8/ND & $0.6 / N D$ & NP/ND & NP/14.1 & NP/0.3 & $\mathrm{NP} / 41$ \\
\hline F-wave & NP/NP & & & NP/NP & & \\
\hline \multicolumn{7}{|l|}{ Ulnar } \\
\hline Wrist & $4.5 / 4.6$ & $0.8 / 0.5$ & & 3.6/NP & $0.6 / \mathrm{NP}$ & \\
\hline Below elbow & $7.4 / 8.3$ & $0.4 / 0.4$ & $61 / 50$ & 8.9/NP & $0.2 / \mathrm{NP}$ & $31 / \mathrm{NP}$ \\
\hline Above elbow & $9.7 / \mathrm{ND}$ & $0.3 / \mathrm{ND}$ & $39 / \mathrm{ND}$ & 12.0/NP & $0.3 / \mathrm{NP}$ & 28/NP \\
\hline Axilla & 11.3/ND & $0.3 / \mathrm{ND}$ & $58 / \mathrm{ND}$ & 14.8/NP & $0.2 / \mathrm{NP}$ & $34 / \mathrm{NP}$ \\
\hline F-wave & NP/NP & & & NP/NP & & \\
\hline \multicolumn{7}{|l|}{ Peroneal } \\
\hline Ankle & NP/NP & NP/NP & & NP/NP & NP/NP & \\
\hline Fibular head & NP/NP & NP/NP & NP/NP & NP/NP & NP/NP & NP/NP \\
\hline Knee & NP/NP & NP/NP & NP/NP & NP/NP & NP/NP & NP/NP \\
\hline F-wave & $\mathrm{NP} / \mathrm{NP}$ & & & $\mathrm{NP} / \mathrm{NP}$ & & \\
\hline \multicolumn{7}{|l|}{ Tibial } \\
\hline Ankle & $4.8 / 4.3$ & $7.1 / 8.3$ & & $5.8 / 5.4$ & $0.3 / 0.7$ & \\
\hline Popliteal fossa & $11.3 / 10.8$ & $5.0 / 6.6$ & $53 / 50$ & $13.9 / 12.9$ & $0.4 / 0.7$ & $41 / 43$ \\
\hline F-wave & NP/NP & & & NP/NP & & \\
\hline \multicolumn{7}{|l|}{ Sensory NCS } \\
\hline \multicolumn{7}{|l|}{ Median } \\
\hline Index-wrist & & $12 / 9$ & $45 / 46$ & & $5 / 6$ & $36 / 41$ \\
\hline Wrist-elbow & & $22 / 20$ & $49 / 52$ & & $18 / 25$ & $45 / 48$ \\
\hline Elbow-axilla & & $45 / \mathrm{ND}$ & 49/ND & & $19 / 24$ & $47 / 47$ \\
\hline \multicolumn{7}{|l|}{ Ulnar } \\
\hline Finger-wrist & & $10 / 14$ & $41 / 35$ & & $6 / 7$ & $36 / 33$ \\
\hline Wrist-elbow & & 49/32 & $51 / 49$ & & 13/11 & $46 / 42$ \\
\hline Elbow-axilla & & 108/ND & $53 / \mathrm{ND}$ & & $26 / 17$ & $46 / 46$ \\
\hline \multicolumn{7}{|l|}{ Superficial peroneal } \\
\hline Lower leg & & $8 / 14$ & $35 / 43$ & & $7 / 11$ & $31 / 37$ \\
\hline \multicolumn{7}{|l|}{ Sural } \\
\hline Lower leg & & $14 / 12$ & $41 / 42$ & & $13 / 16$ & $38 / 39$ \\
\hline H-reflex & NP/NP & & & NP/NP & & \\
\hline \multicolumn{7}{|c|}{ Facial nerve motor NCS } \\
\hline Orbicularis oculi & $3.3 / 2.8$ & $0.1 / 0.1$ & & & & \\
\hline \multicolumn{7}{|l|}{ Blink reflex } \\
\hline |psilateral R1 & NP/NP & & & & & \\
\hline Ipsilateral R2 & NP/NP & & & & & \\
\hline Contralateral R2 & NP/NP & & & & & \\
\hline
\end{tabular}

Data are values on the right/left sides.

NCS, nerve conduction study; NP, no potential; ND, not done. 
of GBS. In addition, albuminocytologic dissociation in the follow-up CSF analysis and the therapeutic response to IVIG strongly supported the diagnosis of GBS in this case.

A previous study found that the prevalence of EBV infection was higher (10\%) in GBS patients than in sex- and age-matched controls. ${ }^{8}$ Tests for EBV serological markers in serum and CSF are sensitive not only for diagnosing EBV infection but also for determining the infection status. ${ }^{6,7}$ Despite a lack of evidence, antiviral agents and steroids are considered for treating the complications of primary EBV infection. ${ }^{9,10}$ However, while GBS is strongly suspected, an accurate and prompt diagnosis is inevitably required to ensure the proper treatment of IVIG or plasmapheresis. ${ }^{4}$ Clinicians should suspect the possibility of supervening GBS in primary EBV infection even when there is clear evidence of CNS infection.

\section{REFERENCES}

1. Kleines M, Schiefer J, Stienen A, Blaum M, Ritter K, Häusler M. Expanding the spectrum of neurological disease associated with Epstein-Barr virus activity. Eur J Clin Microbiol Infect Dis 2011;30:15611569.

2. Häusler M, Ramaekers VT, Doenges M, Schweizer K, Ritter K,
Schaade L. Neurological complications of acute and persistent Epstein-Barr virus infection in paediatric patients. J Med Virol 2002;68:253-263.

3. Kennedy M, Apostolova M. A rare case of infectious mononucleosis complicated by Guillain-Barre syndrome. Neurol Int 2013;5:2022

4. Yuki N, Hartung HP. Guillain-Barré syndrome. N Engl J Med 2012;366:2294-2304.

5. Asbury AK, Cornblath DR. Assessment of current diagnostic criteria for Guillain-Barré syndrome. Ann Neurol 1990;27 Suppl:S21-S24.

6. de Paschale M, Clerici P. Serological diagnosis of Epstein-Barr virus infection: problems and solutions. World J Virol 2012;1:31-43.

7. Portegies $P$, Corssmit N. Epstein-Barr virus and the nervous system. Curr Opin Neurol 2000;13:301-304.

8. Jacobs B, Rothbarth $P$, van der Meché F, Herbrink P, Schmitz P, de Klerk $M$, et al. The spectrum of antecedent infections in Guillain-Barre syndrome a case-control study. Neurology 1998;51:11101115.

9. Torre D, Tambini R. Acyclovir for treatment of infectious mononucleosis: a meta-analysis. Scand J Infect Dis 1999;31:543-547.

10. Tynell E, Aurelius E, Brandell A, Julander I, Wood M, Yao QY, et al. Acyclovir and prednisolone treatment of acute infectious mononucleosis: a multicenter, double-blind, placebo-controlled study. J Infect Dis 1996;174:324-331. 